\title{
A concise tutorial review of TOF-SIMS based molecular and cellular imaging
}

Citation for published version (APA):

Massonnet, P., \& Heeren, R. M. A. (2019). A concise tutorial review of TOF-SIMS based molecular and cellular imaging. Journal of Analytical Atomic Spectrometry, 34(11), 2217-2228.

https://doi.org/10.1039/c9ja00164f

Document status and date:

Published: 01/11/2019

DOI:

10.1039/c9ja00164f

Document Version:

Publisher's PDF, also known as Version of record

Document license:

Taverne

Please check the document version of this publication:

- A submitted manuscript is the version of the article upon submission and before peer-review. There can be important differences between the submitted version and the official published version of record.

People interested in the research are advised to contact the author for the final version of the publication, or visit the DOI to the publisher's website.

- The final author version and the galley proof are versions of the publication after peer review.

- The final published version features the final layout of the paper including the volume, issue and page numbers.

Link to publication

\footnotetext{
General rights rights.

- You may freely distribute the URL identifying the publication in the public portal. please follow below link for the End User Agreement:

www.umlib.nl/taverne-license

Take down policy

If you believe that this document breaches copyright please contact us at:

repository@maastrichtuniversity.nl

providing details and we will investigate your claim.
}

Copyright and moral rights for the publications made accessible in the public portal are retained by the authors and/or other copyright owners and it is a condition of accessing publications that users recognise and abide by the legal requirements associated with these

- Users may download and print one copy of any publication from the public portal for the purpose of private study or research.

- You may not further distribute the material or use it for any profit-making activity or commercial gain

If the publication is distributed under the terms of Article $25 \mathrm{fa}$ of the Dutch Copyright Act, indicated by the "Taverne" license above, 
Check for updates

Cite this: J. Anal. At. Spectrom., 2019 34,2217

Received 10th May 2019 Accepted 28th August 2019

DOI: $10.1039 / c 9 j a 00164 f$

rsc.li/jaas

\section{A concise tutorial review of TOF-SIMS based molecular and cellular imaging}

\begin{abstract}
Philippe Massonnet (iD) and Ron M. A. Heeren (iD *
This concise tutorial review provides a description of the current state of the art in the application of time-of flight based secondary ion mass spectrometry (TOF-SIMS) in the field of molecular and cellular imaging. The application of TOF-SIMS requires a choice of the appropriate beam combined with a signal enhancement method depending on the surface under investigation. The types of detected molecules and methods for molecular identification in SIMS are strongly determined by this combination of ionization method and sample preparation. The use of TOF-SIMS for single cell and three-dimensional imaging will be discussed in the context of selected applications. Finally we will discuss an outlook on the application of the TOFSIMS technology in a multimodal molecular imaging context.
\end{abstract}

\section{Introduction}

The localization and the identification of biochemicals active in biological processes in single cells become more and more important in today's life science research. ${ }^{1-6}$ These needs are supported by the increased necessity to work with small, microscopic amounts of materials such as small biopsies, fine needle aspirates and cell smears for early diagnosis. The study of the chemical communication between cells is crucial for a better understanding of biological processes. ${ }^{1}$ The localization and the quantitation of multiple analytes (peptides, lipids,

Maastricht MultiModal Molecular Imaging (M4I) Institute, Maastricht University, Maastricht, Netherlands.E-mail: r.heeren@maastrichtuniversity.nl metabolites, ...) is a key target. Mass spectrometry imaging (MSI) is a commonly used technique that offers the advantage to detect multiple classes of atoms and molecules on a surface in parallel. With MSI, the sample is put onto a surface and the sample is interrogated on a pixel-by-pixel basis. A mass spectrum is acquired for each pixel such that different analytes can be located on the surface.

Among all existing MSI techniques, secondary ion mass spectrometry (SIMS) imaging is the technique that currently offers the highest lateral resolution.

SIMS imaging is a technique based on the bombardment of a surface with an energetic primary ion beam. Secondary ions are ejected from the sample (positively or negatively) as a result of this bombardment and can be analyzed further in the mass

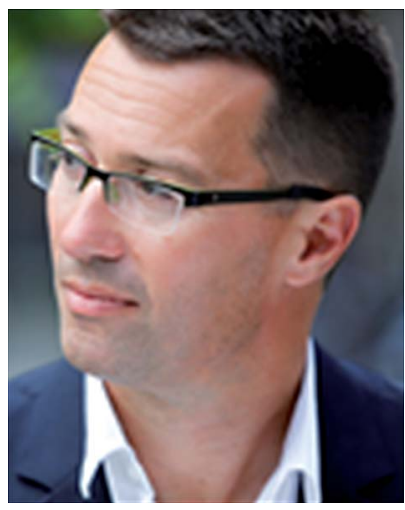

Prof. Dr Ron M. A. Heeren (1965) is a distinguished professor and Limburg Chair at the University of Maastricht. He is the director of the Maastricht MultiModal Molecular Imaging (M4I) Institute and heads the division of imaging mass spectrometry. He has developed innovative approaches towards high spatial resolution and high throughput molecular imaging technologies to study the complexity of interfaces. He has a strong interest in translational molecular imaging for tissue typing in personalized medicine.

currently a post-doctoral fellow at the Maastricht MultiModa Molecular Imaging (M4I) institute in the mass spectrometry imaging division (Prof. Heeren) at Maastricht University (Netherlands) and his research interest includes SIMS instrumental and method developments for biological sample analysis. 
spectrometer. In SIMS, two types of strategies exist: ${ }^{7,8}$ static and dynamic SIMS. In static SIMS, ion doses for bombardment are relatively small, ${ }^{8}$ while in dynamic SIMS, the doses are higher which makes dynamic SIMS more destructive. ${ }^{9}$ This approach is often employed for depth profiling a surface. The transition between static and dynamic SIMS is globally defined as the socalled "static limit" fixed at an ion dose of $10^{13}$ ions $\mathrm{cm}^{-2}$. Within this review, only static-SIMS will be discussed. Details about the fundamental desorption and ionization mechanisms are also not discussed in this review and can be found in several publications on the topic. ${ }^{\mathbf{1 0 - 1 2}}$ Compared to matrix-assisted laser desorption ionization (MALDI) mass spectrometry imaging (MSI), SIMS imaging offers the advantages of not requiring either a label or a matrix. ${ }^{13}$ In addition, even if MALDI imaging has made significant progress recently in terms of lateral resolution, the maximum obtainable lateral resolution of SIMS imaging exceeds the MALDI MSI spatial resolution., ${ }^{6,14}$ On the other hand, SIMS is limited in term of mass range compared to MALDI. The sensitivity of SIMS can be improved using different strategies (discussed later in this manuscript).

Within this review, we will first discuss the types of primary ion beams that are used to generate secondary ions from an organic surface. Next, we will discuss methods used to enhance the signal and allow different molecular classes to be analyzed with SIMS.

In the second part of the manuscript, an overview of the different methods that are used to perform molecular identification of the ions will be provided. Finally, selected methods and applications of three dimensional SIMS imaging will be discussed.

\section{Beam choice in SIMS}

Different beams can be used for SIMS imaging measurements. The choice depends strongly on the application targeted. An overview of different beams used in SIMS measurement with their references is provided in Table 1 .

A large variety of beams have been described in the literature. Here, we have chosen to exclusively discuss the most commonly used beams for biological/organic sample analysis. Schematically, two types of beam can be used: metal/atomic ion beams and ion cluster beams. Early ion beam research ${ }^{26,28-30}$ demonstrated that working with cluster ion beams provides substantial advantages such as significant increase of the molecular ion yields, ${ }^{31}$ significant extension of the useable mass range for mass spectrometry analysis and minimization of beam-induced damage on and below the surface. For these reasons, use of ion cluster beams is the method of choice for chemical analysis of biological surfaces. One example that illustrates the benefits of working with an ion cluster beam instead of a classical ion beam is depicted in Fig. 1. In this figure, the distribution of a phosphocholine ion at $\mathrm{m} / \mathrm{z} 184$ on a cellular surface is depicted and the results show clearly that the $\mathrm{C}_{60}{ }^{+}$ion beam provides more molecular signal than the $\mathrm{In}^{+}$ atomic ion beam (nearly 3 orders of magnitude).

Concerning the drawbacks, the cluster ion beams cannot be focused easily and typically result in a lower spatial resolution compared to atomic ion beams. Additionally, the cluster beams are less suitable for elemental analysis. In practice, polyatomic ion beams such as Bi or Au cluster beams can operate in either single ion or in cluster mode using beam filtering. A large variety of $\mathrm{Bi}$ clusters as well as monoatomic species can be generated depending on the emission current. ${ }^{22}$

A comparison of different relative secondary ion yields of cluster ion beams $\left(\mathrm{C}_{60}{ }^{+}, \mathrm{Ar}^{n+}\right.$ and $\left.\left(\mathrm{H}_{2} \mathrm{O}\right)^{n+}\right)$ for isolated and mixed amino acids (arginine and histidine) has been performed by Alnajeebi et $a l .{ }^{33}$ This study has pointed out the fact that the water cluster beam gives the highest yields for pure amino acids (protonated species) as well as in mixtures.

A direct comparison of $\mathrm{Au}^{3+}$ and $\mathrm{C}_{60}$ ion beams has also been communicated in the literature. ${ }^{19}$ This article has pointed out the possibility to combine both beams for three dimensional imaging. This application will be discussed later in this review.

As presented in Table 1, large gold clusters $\left(\mathrm{Au}_{400}{ }^{4+}\right)$ have also been investigated for their suitability for molecular imaging. ${ }^{\mathbf{2 0 , 3 4 , 3 5}}$ Using these clusters, ion yield enhancements of 1000 and signal-to-noise improvements up to a factor of 20 were described. In addition, remarkably low damage cross-sections were also reported for gramicidin $\mathrm{S}$ and dynorphin. ${ }^{\mathbf{3 4}}$

In addition to these beams, massive glycerol clusters have been tried for SIMS imaging measurements. ${ }^{36,37}$ However, these

Table 1 Overview of beams employed for SIMS imaging experiments

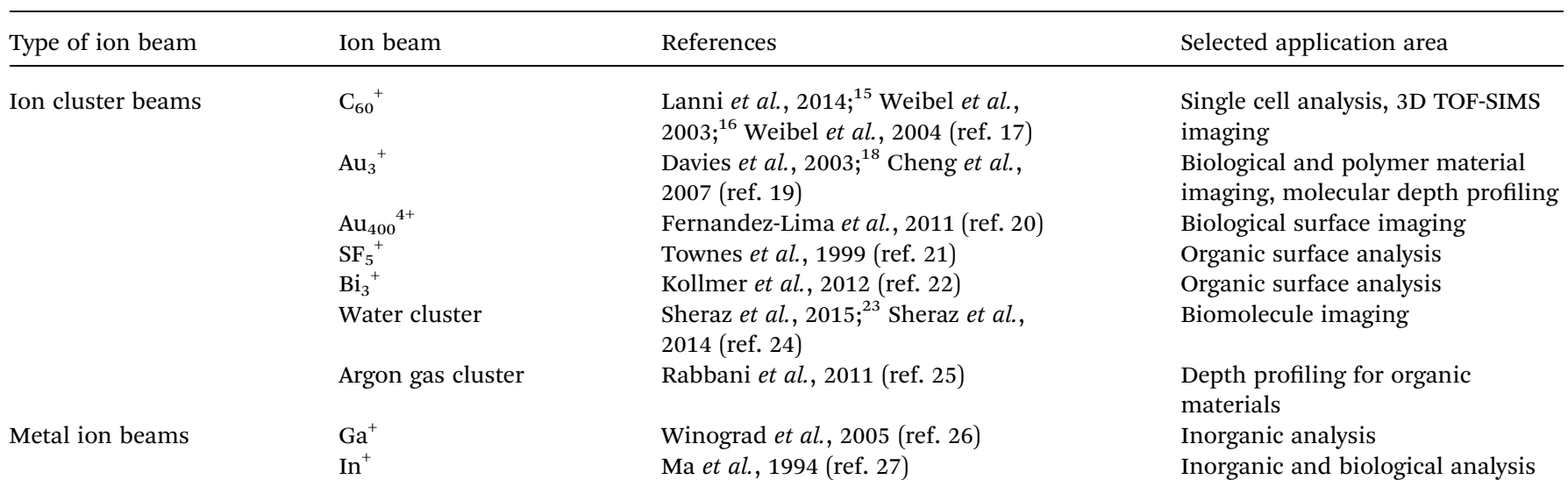



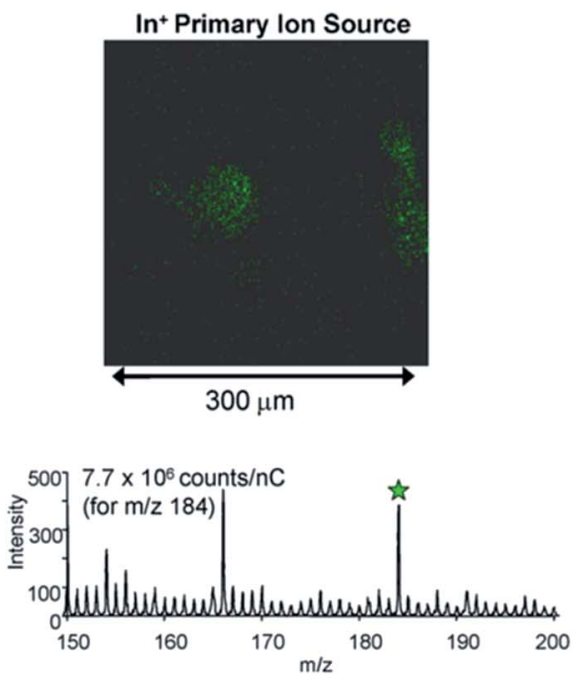
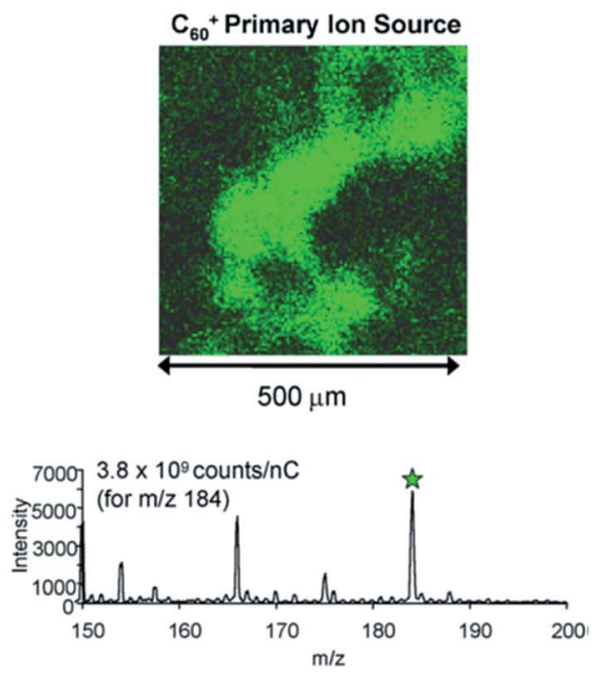

Fig. 1 Yield enhancement from freeze-dried Tetrahymena cells. Reprinted from Ostrowski et al. (2004), ${ }^{32}$ copyright 2004, with permission from Elsevier.

beams have been little used because of their poor lateral resolution and surface contamination they can cause.

\section{Signal enhancement methods}

When the obtained signal after SIMS measurement is not high enough, chemical surface modifications can be employed. This can be combined with the developments in ion cluster beam technology. ${ }^{38,39}$ Until now, there are mainly two types of surface modifications to enhance the ionization efficiency: metal assisted (MetA) SIMS ${ }^{\mathbf{4 0 - 4 2}}$ and matrix-enhanced (ME) SIMS. ${ }^{43}$

MetA SIMS typically uses gold and silver deposition on the surface. ${ }^{\mathbf{3 8 , 4 4}}$ These deposited nanolayers result in metal adduct formation of the molecules of interest and allow the detection of molecules with higher molecular masses. This results in an enhancement of the ionization efficiencies of specific molecules.

For example, silver has been shown to efficiently enable the detection and the localization of cholesterol in rat kidney sections ${ }^{45}$ while gold has been used for polymer analysis ${ }^{46}$ and the detection of kilodalton molecules. ${ }^{47}$ MetA SIMS has also been shown useful to reduce the influence of the chemical environment on the ion yields (referred to as a change of the "matrix effect" in the literature). ${ }^{48}$ MetA SIMS has enhanced small molecule ion detection on biofilms ${ }^{49}$ as well as the signal of small organic compounds such as peptides ${ }^{50}$ and additive molecules in tissue. ${ }^{51,52}$ Typically, the thickness of the gold coating is about $1 \mathrm{~nm}$. One drawback of this method is increased spectral complexity and an associated difficulty to assign spectral peaks. Multiple analyte/metal stoichiometries can be found, ${ }^{\mathbf{4 3}}$ making the assignment difficult. In addition, the time between metal-deposition and the analysis plays an important role in the detected signal, and results in reduced reproducibility. Gold and silver nanoparticles have also been successfully employed for signal enhancement in SIMS measurements. ${ }^{53}$

From a mechanistic point of view, the exact mechanism that leads to enhanced sputter yields is still under debate.
Increased stopping power (the kinetic energy loss from the primary particle per unit path length in the sample surface), reduced surface charging and altered gas-phase ion chemistry have all been postulated as possible causes. No solid experimental evidence exists that exclusively supports any of these theories.

Over the last few years, MetA SIMS has been used routinely in different research areas such as forensic hair analyses. ${ }^{54,55} \mathrm{ME}-$ SIMS requires the matrix to be deposited on the sample before SIMS analysis to enhance the ionization efficiency of the analyzed molecule. Generally, commonly used MALDI matrices such as $\alpha$-cyano-4-hydroxycinnamic acid (CHCA) or 2,5-dihydroxybenzoic acid (DHB) are used. For this reason, ME-SIMS is often considered as a mixture of SIMS and MALDI. However, in the case of ME-SIMS, the matrix choice is not constrained by its photon absorption characteristics. ${ }^{56}$ This opens then the door to the use of a large variety of matrices in ME-SIMS.

In terms of applications, ME-SIMS has been useful for the enhancement of ionization efficiencies of gramicidin $S$ in negative mode using sinapic acid as the matrix, ${ }^{57}$ to generate molecular ions of small proteins ${ }^{58}$ and lipids such as phosphatidylcholine. ${ }^{59}$ In the tissue, cholesterol as well as several neuropeptides were successfully detected using ME-SIMS. ${ }^{\mathbf{6 0 , 6 1}}$

Recently, ME-SIMS has been used in a high-throughput method for single cell profiling of neuronal cells. ${ }^{62}$

In some cases, ME-SIMS and MetA-SIMS are used in combination on one sample in order to enhance the analyte signal even further through collective action. ${ }^{43}$

\section{Types of biological molecules detected by SIMS}

This section will focus on the opportunities and limitations of SIMS analysis of peptides, DNA, lipids and other small molecules. The analysis of fragments of adsorbed proteins will also be discussed. 


\section{a Protein and peptide analysis using SIMS}

In the field of protein analysis, SIMS has mainly been used to characterize adsorbed proteins on a surface. ${ }^{63-71}$ In these studies, protein fragments were detected and multivariate analysis such as principal component analysis (PCA) was applied to identify the adsorbed proteins. As stated in these studies, the biggest advantages of PCA are the ease of use, the direct identification of groups of interest, and the nonnecessity of prior knowledge of the considered system. However, a peak preselection is sometimes required to distinguish groups and PCA is not helpful for noisy data. Protection and fixation methods were also employed to preserve original adsorbed protein structures (sugar protection and glutaraldehyde cross-linking for example). ${ }^{72}$ TOF-SIMS has also been used in addition to surface plasmon resonance (SPR) in order to evaluate the orientation of a surface-immobilized protein. ${ }^{73}$ The biggest advantage of TOF-SIMS in the field of adsorbed proteins is its sensitivity (for example, ability to detect low amount of adsorbed proteins $\left.(\sim 1 \mathrm{ng} \mathrm{cm})^{-2}\right)$ on a wide variety of surfaces). ${ }^{66}$ The biggest drawback of SIMS is the difficulty to detect intact proteins (which MALDI can do). Indeed, only fragments are detected, which makes the data treatment more complicated.

In addition to proteins, peptides can be detected and sequenced using ME-SIMS ${ }^{74}$ on a tandem TOF system. Solid phase peptide syntheses can also be monitored using TOFSIMS. ${ }^{75}$ On-tissue enzymatic digestions followed by TOF-SIMS analyses have also been tested on pig thyroid glands. ${ }^{76}$ In this article, a Bi ion cluster beam has been used and high resolution molecular images of resulting peptides were obtained. On the other hand, the biggest drawback of this method is the peptide diffusion during the digestion process.

\section{b DNA analysis using SIMS}

In the field of nucleic acids, unknown DNA fragments were successfully detected and fragmented using SIMS. ${ }^{77,78}$ DNA microarrays were also successfully imaged using SIMS imaging. ${ }^{79}$ The authors demonstrated the complementarity of this technique with other imaging techniques such as fluorescence and X-ray photoelectron spectroscopy (XPS) in a true multimodal imaging manner. TOF-SIMS imaging results have also been compared to high-resolution epifluorescence results, ${ }^{80}$ and could be of interest in the field of DNA microarraybased diagnostics.

\section{c Lipid and small molecule analysis using SIMS}

Usually and according to the IUPAC recommendations, ${ }^{81}$ lipids can be defined as "substances of biological origin that are soluble in nonpolar solvents". Lipids are important compounds in all cells and play important roles in the nuclear membrane for example. ${ }^{82}$ In that context, an in-depth analysis of the lipid composition of cells is crucial.

Among all biological molecules, lipids have been studied most extensively with SIMS. ${ }^{83-85}$
Lipids coming from brain tissues, ${ }^{\mathbf{8 6}-90}$ cell membranes, ${ }^{\mathbf{9 1}}$ microbial mat, ${ }^{92}$ non-alcoholic fatty liver ${ }^{93}$ or muscles ${ }^{94}$ have, for example, been studied using SIMS imaging experiments.

In the microbial mat study, ${ }^{92}$ SIMS imaging (using a Bi ion cluster source) was, for example, useful in order to identify a series of lipid microbial biomarkers. The high lateral resolution accessible through SIMS was, in this case, a key capacity in order to resolve the lipid distribution in such samples.

In muscles, ${ }^{94}$ static SIMS has made possible the localization of various lipids such as diacylglycerol (DAG), triacylglycerol (TAG) or cholesterol. In this article, the combined use of positive and negative mode was useful in order to detect as many lipids as possible.

The lipid composition of the cerebral cortex of Alzheimer's disease patients have successfully been characterized using SIMS imaging. ${ }^{95}$ In this study, the limit between grey and white matters has been found to be linked to cholesterol levels. Within the grey matter, cholesterol levels have been shown to be $34 \%$ higher in Alzheimer's disease patients than in control patients.

Lipid distributions were also determined with SIMS on single cells, ${ }^{96}$ adipose tissues ${ }^{97}$ and on rat spinal cord. ${ }^{98}$

When analyzing lipids and more generally biological samples using SIMS in positive mode, one ion at $\mathrm{m} / z 184$ is often detected. This ion is associated with the phosphocholine headgroup of various lipid moieties. ${ }^{91}$ In positive mode, cholesterol is often detected in two different forms ([cholesterol $-\mathrm{H}]^{+} ; m / z 385$ and [cholesterol $\left.-\mathrm{H}_{2} \mathrm{O}+\mathrm{H}\right]^{+} ; m / z$ 369) while using the MetA-SIMS approach with gold coating, cholesterol is often detected in other forms ${ }^{99}$ like $[2 \text { cholesterol }-\mathrm{H}+\mathrm{Au}]^{+}$at $m / z 970$.

Some small molecules such as vitamin E can also be detected using TOF-SIMS in biological samples. ${ }^{100}$ In this work, vitamin E has been shown to be significantly present at the stroma-neurite junction compared to the whole cell. Concerning other small molecules, metabolic profiling of diseases has already been performed using TOF-SIMS and PCA analysis. ${ }^{\mathbf{1 0 1}}$

\section{Molecular identification}

In order to perform ion identification, two methods can be used: high mass accuracy identification and tandem mass spectrometry analysis.

Concerning the high mass accuracy, Fourier transform ion cyclotron resonance mass spectrometry (FT-ICR MS) is used in combination with SIMS capabilities. ${ }^{\mathbf{1 0 2 - 1 0 7}}$ Even if they are expensive and located in few laboratories in the world, such instruments were able to provide mass resolutions above $3000000\left(\mathrm{~m} / \Delta m_{50 \%}\right)$ that enable the unambiguous molecular identification of ions based on the mono-isotopic peak and the isotopic profile in combination with high lateral SIMS resolution.

In parallel to this high mass accuracy identification, tandem mass spectrometry (MS/MS) has been recently combined with SIMS to validate/determine the molecular composition and the structure of the detected ion. Such experiments were, for example, performed on lipids using a TOF-SIMS instrument 
equipped with MS/MS capabilities. ${ }^{\mathbf{1 0 8 - 1 1 0}}$ In this instrument, a high-energy collision cell is present as well as a second TOF detector to allow simultaneous MS and MS/MS detection for an efficient mass spectrometry imaging experiment. In this way, localization and quantification, using SRM/MRM types of approaches, can be performed in parallel to molecular identification. SRM/MRM approaches are based on consecutive selection of a single precursor ion, collision induced fragmentation and a single selected specific reaction product ion, often coupled with triple quadrupole mass spectrometers. This approach allows for example the quantitative analysis of drugs and their metabolites in complex biological mixtures.

One example of such SIMS MS/MS experiment is depicted in Fig. 2 where the erucamide structure has been revealed including the position of the double bond using charge remote fragmentation induced by high energy CID. The same experiment has also been performed successfully on endogenous neuropeptides using ME-SIMS. ${ }^{74}$ SIMS MS/MS experiments have also been performed on DNA ${ }^{77}$ and on cholesterol. ${ }^{111}$ Similar to FT-ICR instruments, these SIMS MS/MS systems are expensive and are found in few laboratories in the world.

SIMS MS/MS fragmentation of pure peptides has also been performed on another instrumental setup using Ar cluster beams and $\mathrm{C}_{60}$ ion beams of various intensities. ${ }^{112}$

\section{3D imaging using SIMS}

As already mentioned earlier in this review, the appearance of ion cluster beams has opened the door to new applications of SIMS imaging that include the possibility to perform three dimensional imaging. In comparison with conventional 3Dimaging techniques such as 3D immunohistochemistry, SIMS 3D imaging presents the advantage of being label-free, sensitive, having a broad molecular coverage and provides excellent lateral resolution.

Different approaches have been detailed and explained in the literature but in this section, we will focus on two approaches: serial sectioning ${ }^{\mathbf{1 1 3}}$ and ablation. ${ }^{\mathbf{1 1 4}}$

\section{a Serial sectioning}

Serial sectioning is currently the most commonly used technique to perform $3 \mathrm{D}$ visualization of SIMS-imaging results. ${ }^{113,115,116}$ One of the first 3D reconstructions from SIMS imaging data was published in 2012 by Fornai et al. ${ }^{117}$ where a 3D molecular map of a rat heart was obtained from 40 serial cuts of the heart. In this example, principal component analysis (PCA) was used in order to put in evidence useful information out of very complex and large datasets. A detailed explanation of the used workflow is presented in Fig. 3.

Fig. 3 shows the 3D distribution of sodium $(23 \mathrm{~m} / \mathrm{z})$ as well as potassium $(39 \mathrm{~m} / \mathrm{z})$ in the heart. The biggest advantage of this approach is the relative non-destructive character of this method. As a result, other targeted histological staining techniques (using fluorescence for example) can be performed on the serial slides following the SIMS imaging experiments. In addition, this method allows a parallel detection of multiple compounds without any needed prior knowledge about their nature. From that point of view, this method is a "full discovery" method. On the other hand, this approach is relatively time consuming and requires a lot of computational efforts to visualize the results. Different computational strategies have been developed in order to make this possible. ${ }^{\mathbf{1 1 8 - 1 2 0}}$

\section{b Ablation}

Next to the serial sectioning approach, ablation or sputtering of the sample surface, layer after layer, can also be performed in order to get $3 \mathrm{D}$ information in only one experiment. In this approach, which is a combination of dynamic and static SIMS, an analytical beam is first used for surface imaging. Then, the sample is sputtered (above the static limit) in order to make an underlying layer available for image acquisition. Subsequently, the analytical beam is used for surface imaging again. This succession of analytical/sputter beams is applied until the required depth of the sample surface is analyzed.

3D in-depth molecular imaging of Xenopus laevis oocytes has for example been performed using a $\mathrm{C}_{60}$ ion cluster beam for sputtering and analysis. ${ }^{\mathbf{1 2 1}}$ In this publication, the obtained peaks are associated with cholesterol and lipids in the mass

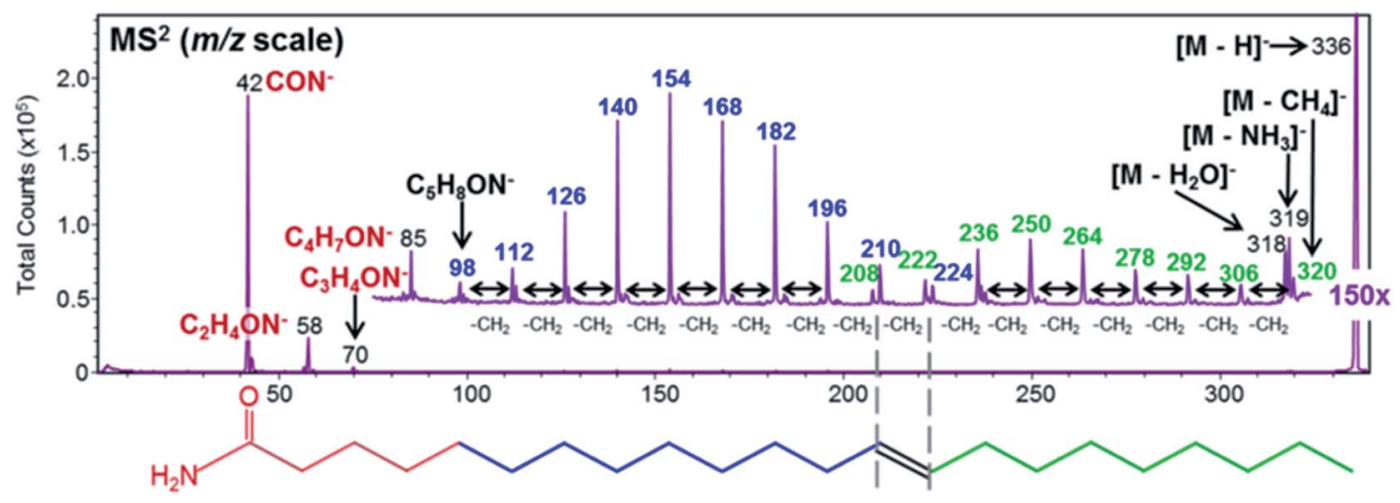

Fig. $2 \mathrm{CID}$ ion spectrum of the precursor ion at $\mathrm{m} / \mathrm{z} 336$ (negative mode) produced from a spotted reference of erucamide. This ion was identified as palmitic acid and the structure of this molecule is depicted bellow the MS/MS spectrum. Reprinted from Fisher et al.(2016), ${ }^{108}$ copyright 2016, with permission from ACS. 


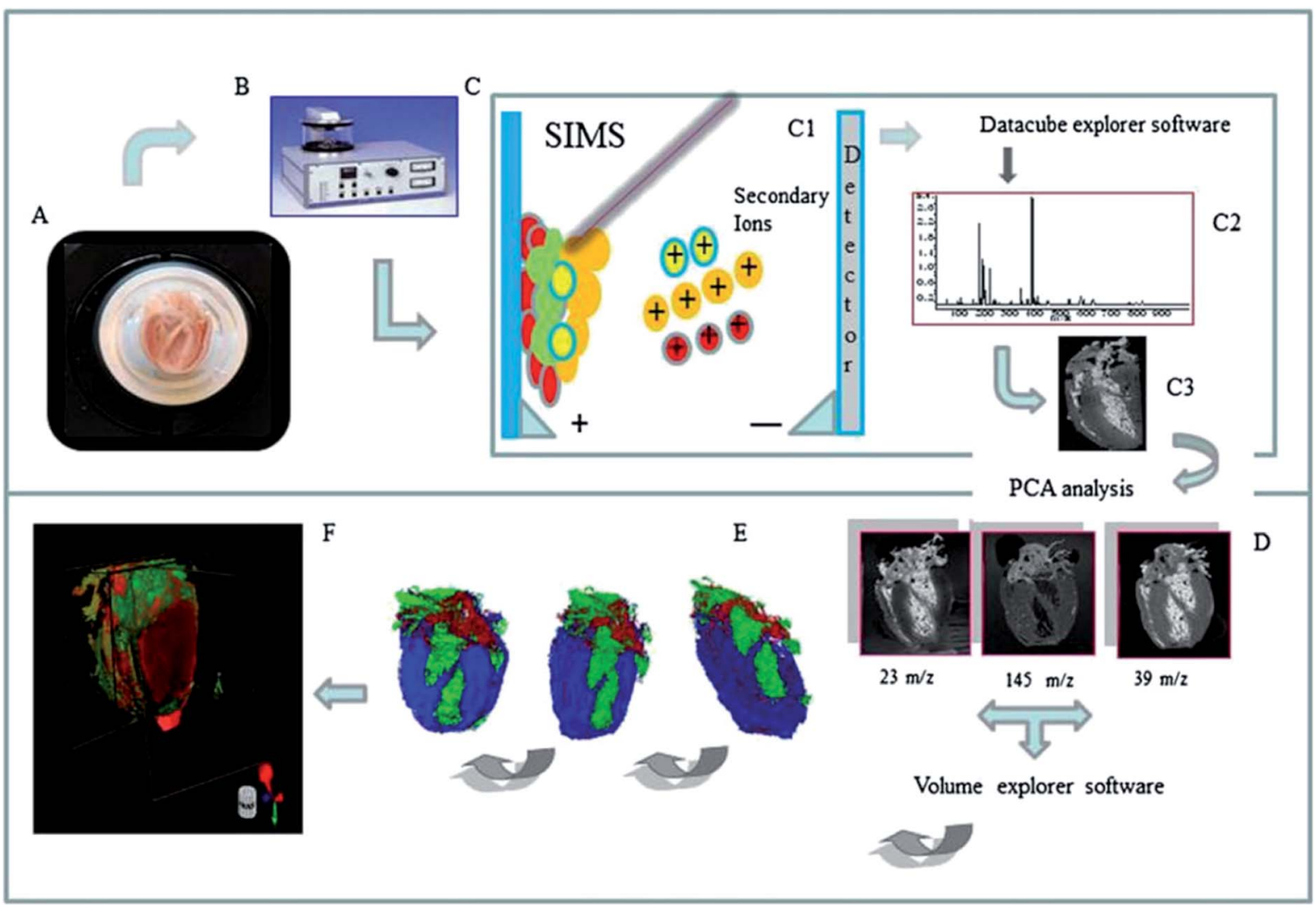

Fig. 3 Used workflow for 3D image construction from serial slides; (A) tissue section; (B) gold deposition; $\left(C_{1}\right)$ SIMS-TOF mass analyzer; $\left(C_{2}\right)$ mass spectral peaks; $\left(C_{3}\right)$ datacube images; ( $D$ and E) 3D reconstruction of rat heart. Spatial distributions of $23 \mathrm{~m} / \mathrm{z}$ (green), $39 \mathrm{~m} / \mathrm{z}$ (blue) and $145 \mathrm{~m} / \mathrm{z}$ (red); (F) co-registration of 40 mass spectrometry imaging experiments. Reprinted from Fornai et al.(2012), ${ }^{117}$ copyright 2012, with permission from Springer.

ranges of $m / z 540-570$ and $m / z$ 800-1000 respectively in positive ion mode. HeLa cells have also been imaged using $\mathrm{C}_{60}$ beam alone or $\mathrm{C}_{60}$ combined with $\mathrm{Bi}_{3}$ cluster beam. ${ }^{122,123}$ The combined use of two different cluster ion beams allows low destructive measurement $\left(\mathrm{Bi}_{3}\right.$ cluster beam) followed by an etching beam that is more efficient to perform ablation of organic surfaces $\left(\mathbf{C}_{60}\right.$ beam). Strategies which employ cluster beams to remove subsurface sputter damage and reinstate molecular signal from the surface have been successfully deployed as well. ${ }^{\mathbf{1 2 4}}$ Recently, Castellanos et al. used $\mathrm{Bi}_{3}$ cluster beam (for surface analysis) and Ar cluster beam (for surface ablation) in order to perform 3D imaging of Aedes aegypti ovarian follicles. ${ }^{\mathbf{1 2 5}}$

Peptide incorporation within two MALDI matrix crystals $(2,5-$ dihydroxybenzoic acid (DHB) and $\alpha$-cyano-4-hydroxycinnamic acid (CHCA)) has been investigated using SIMS sputtering. ${ }^{\mathbf{1 2 6}}$ In this study, argon cluster and $\mathrm{Bi}_{3}{ }^{+}$beams have been used in concert. More recently, chemotherapeutic drug delivery has been investigated at a single cell level using TOF-SIMS. ${ }^{127}$

In some studies, atomic force microscopy (AFM) and scanning electron microscopy (SEM) are also used to evaluate the rate and the efficiency of the sputter process. ${ }^{\mathbf{1 2 8 - 1 3 0}}$ Other studies used multilayer Irganox standard samples to calibrate the sputtering efficiency as a function of $z$ height and determine a depth scale. ${ }^{\mathbf{1 3 1 - 1 3 3}}$ These Irganox standard samples are composed of a given succession of various layers of known compounds. The composition as well as the distance between the layers is known and this information is used to calibrate the $z$-scale and, consecutively, to relate the time of sputtering with the thickness of the removed material. However, these Irganox standard samples can only provide estimations of organic sputtering rates as the sputtering yields of standard samples will always be different than those of real biological samples. Moreover, sputtering efficiencies have been shown to be dependent on the surface temperature. These convolved, complex processes require appropriate organic calibration samples for accurate 3DSIMS imaging and depth profiling.

\section{TOF-SIMS application: single cell analysis}

One of the most impressive applications of TOF-SIMS has been shown in 2013 by Leefmann and coworkers. ${ }^{134}$ In this paper, as shown in Fig. 4, fatty acid cellular localization on cryosections of a phototropic microbial mat has been performed in negative mode using a TOF-SIMS instrument. Fig. 4 shows specific distributions of various biomarkers such as triacylglycerol 
(a)
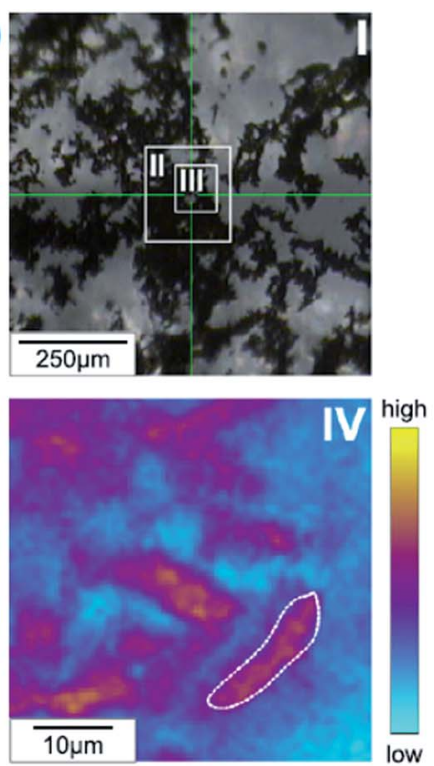
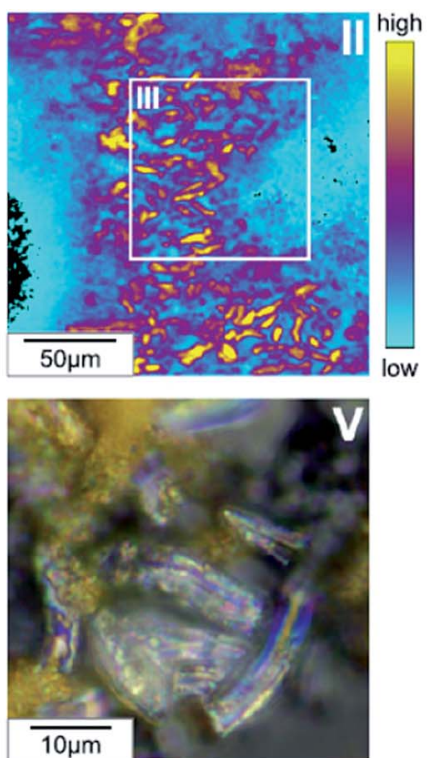

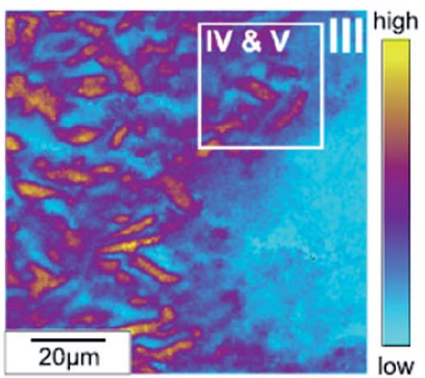

VI

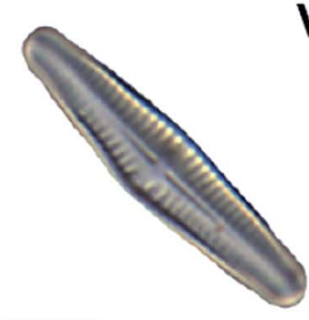

$5 \mu \mathrm{m}$

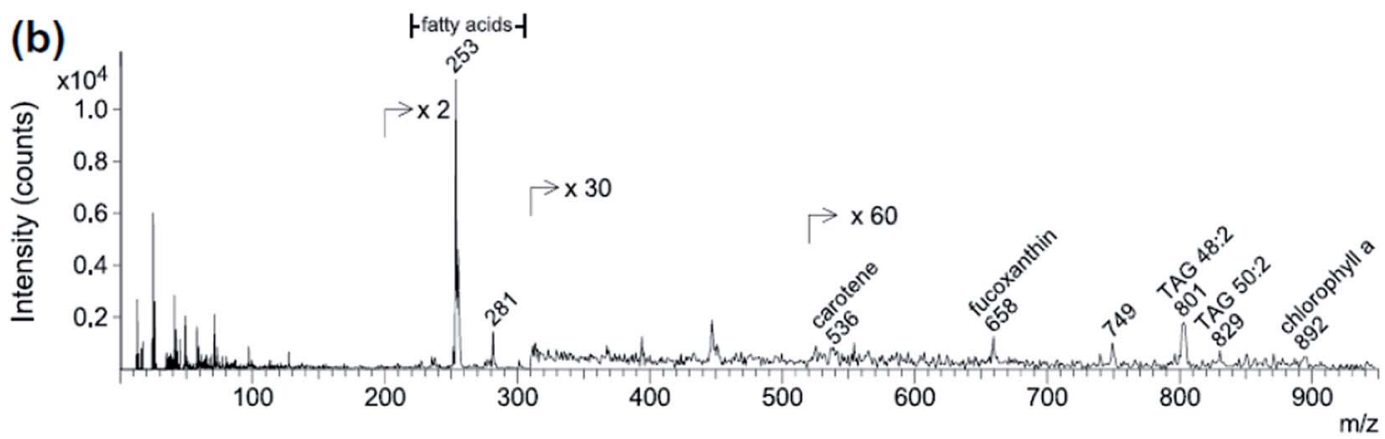

Fig. 4 Single cell biomarker imaging: (a) microscopic and ion images of the phototrophic microbial mat cryosection analyzed in burst alignment mode (I) ToF-SIMS built-in video camera image with areas analyzed marked by white frames, (II) ion image of $200 \mu \mathrm{m} \times 200 \mu \mathrm{m}$ area showing distribution of summed C16 and C18 fatty acids (negative ion mode, $\mathrm{m} / \mathrm{z} 251-258+\mathrm{m} / \mathrm{z} 275-284$ ), (III) ion image of $100 \mu \mathrm{m} \times 100 \mu \mathrm{m}$ area showing distribution of summed C16 and C18 fatty acids, (IV) enlarged detail of (III) showing enrichment in C16 and C18 FAs in a diatom cell [white, dashed line marks the area from which the spectrum in (b) was calculated], (V) fluorescence microscopic image from the area corresponding to (IV) after ToF-SIMS measurements, showing accumulation of diatom cells, (VI) single cell of a predominant diatom, Planothidium lanceolatum, in the microbial mat. (b) Partial negative burst alignment mode ToF-SIMS spectrum $(\mathrm{m} / \mathrm{z} 0-950)$ of a single diatom cell in the microbial mat cryosection corresponding to the area marked in (a) IV. TAG (triacylglycerol). Reprinted from Leefmann et al. (2013). ${ }^{134}$ Copyright 2013. With the permission of Elsevier.

(TAG) and fatty acids on the microbial mat. Fatty acids with various hydrocarbon chain lengths (C16 and C18) have, for example, been found. This example demonstrates the advantages of TOF-SIMS for biological samples: no sample treatment is needed (or mandatory) and the obtained lateral resolution allows the investigation of single cell processes. The obtained results are correlated with other established techniques such as microscopy in order to obtain a more complete map of the system under study.

The use of TOF-SIMS for the detection of lipids or small molecules (such as cocaine) on single cell surfaces has been considered in various other publications. ${ }^{6,135,136}$

In all the above-mentioned research, even if no sample treatment is needed for TOF-SIMS imaging, the results put in evidence a couple of precautions that need to be taken in order to push the quality of molecular information obtained from cellular compounds.
First, due to the intrinsic surface sensitivity of TOF-SIMS and other mass spectrometry imaging techniques, the sample preparation plays an important role in the imaging process. ${ }^{137}$ For example, when working under cryogenic conditions, the signal interferences generated by the possible presence of water on the surface have to be minimized. To do so, different strategies can be used in order to avoid water condensation at the surface. ${ }^{135,136}$ These strategies imply slight sample heating under vacuum in order to remove most of the water. In order to make easier the sample sectioning in a cryomicrotome at $-20{ }^{\circ} \mathrm{C}$, other sample preparation methodologies such as embedding before sectioning can be considered. In this case, polymer-based embedding materials are generally avoided in order to prevent sample contamination. Instead, agarose or $10 \%$ gelatin materials are preferred. For room-temperature samples, those can, for example, be embedded in paraffin before sectioning at room temperature. ${ }^{138}$ 


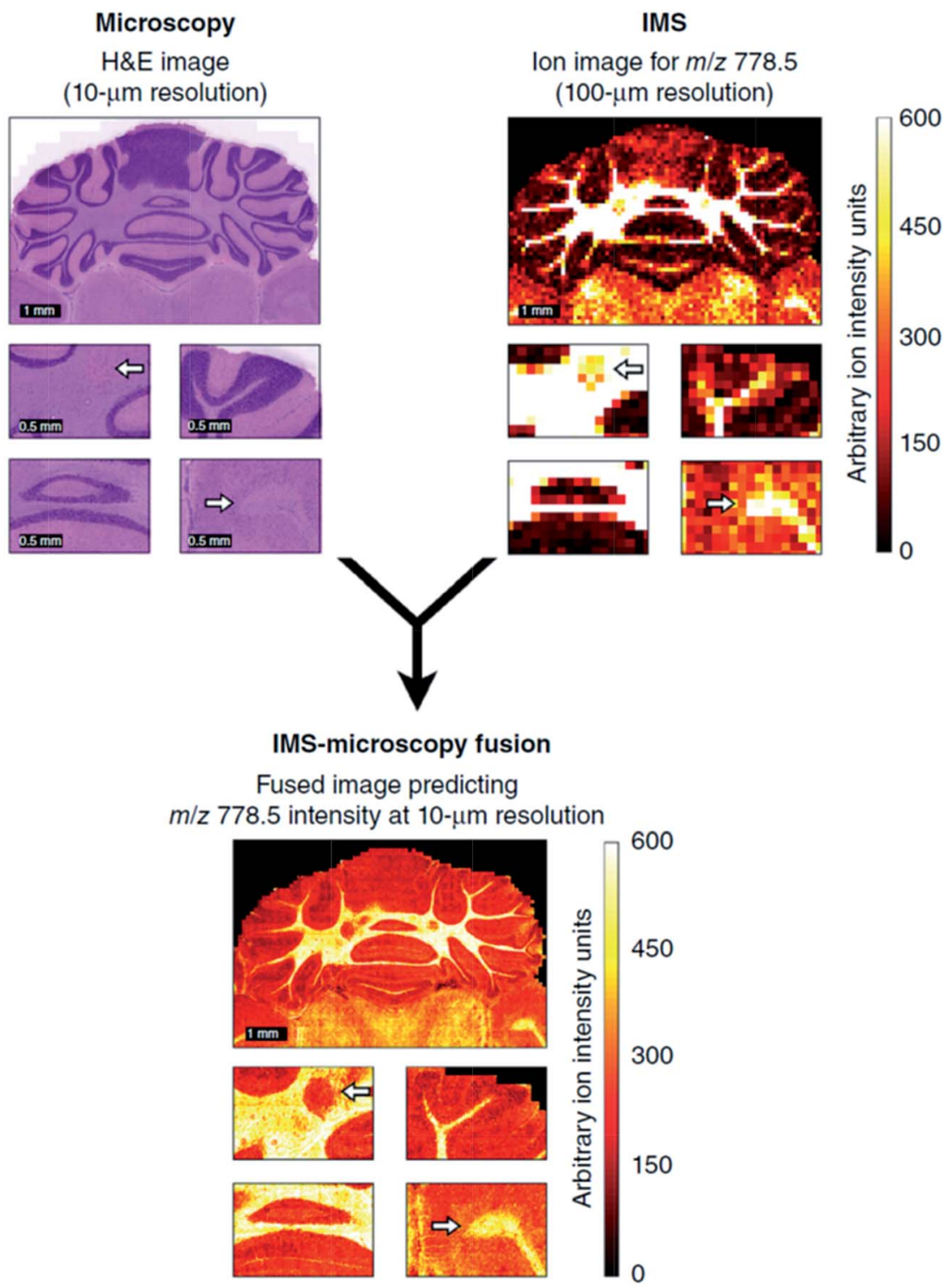

Fig. 5 Obtained ion image ( $\mathrm{m} / \mathrm{z}$ 778.5; lipid $\mathrm{PE}(\mathrm{P}-40: 4))$ of a mouse brain at $10 \mu \mathrm{m}$ resolution after merging H\&E stained microscopy image and MALDI mass spectrometry imaging. Reprinted from Van de Plas et al., ${ }^{144}$ copyright 2015, with permission from Nature.

Second, as TOF-SIMS is a surface analysis technique, any external contamination such as the culture medium needs to be removed prior to analysis.

Thirdly, the structures of interest have to be at the surface of the sample. Finally, the compound of interest has to exhibit a sufficient secondary ion yield for efficient detection. This requirement is especially difficult if the considered compound has a high molecular weight or if it is present at extremely low concentration on the sample surface. Moreover, the ionization efficiencies of the considered sample are often influenced by the analyte environment (often referred to as the 'matrix effect' in the SIMS area). ${ }^{26}$

\section{Conclusion and outlook}

Within this review, different recent applications of TOF-SIMS imaging for molecular and cellular imaging are described and discussed. Overall, these studies point out that the beam choice as well as the chosen method for signal enhancement is crucial for efficient molecular imaging of complex surfaces. The commercial availability of ion cluster beams such as $\mathrm{C}_{60}, \mathrm{Bi}_{3}$ or $\left(\mathrm{H}_{2} \mathrm{O}\right)_{n}$ has revolutionized the world of biological SIMS-imaging as it enables the detection of molecules with higher molecular weights and 3D molecular mapping of a sample in a single experiment. The combined use of different ion beams has also been shown to be useful for such experiments. These ion cluster beams can also be used complementary to other methodologies such as MetA-SIMS and ME-SIMS that enhance the ionization efficiency. Moreover, TOF-SIMS imaging is best used in a multimodal setting, i.e. in combination with other imaging techniques to obtain an appropriate view of the sample considered. ${ }^{139}$ Combination of SIMS with AFM and/or SEM is, for example, useful to completely map samples on a morphology and molecular level. TOF-SIMS is demonstrated to be an efficient technique for single cell analysis. 
While the use of high mass-resolution instruments such as FT-ICR in combination with SIMS can be useful for molecular identification, the majority of the identification methods focus on tandem mass spectrometry.

In the future, SIMS-imaging will be seamlessly integrated into a multimodal imaging environment where it is combined with other morphological and molecular imaging methods. Integration of this technology with fluorescence techniques such as multiphoton microscopy ${ }^{\mathbf{1 4 0}}$ or fluorescence lifetime imaging microscopy (FLIM) ${ }^{\mathbf{1 4 1}}$ will give rise to unique results and provide better understanding of cellular processes and metabolism. SIMS (including ME-SIMS and MetA-SIMS) and MALDI imaging experiments will be more and more used ${ }^{\mathbf{1 4 2 , 1 4 3}}$ in combination in order to compensate each other's limitations. MALDI imaging is able to detect molecules with high molecular masses (up to tens of $\mathrm{kDa}$ ) but limited in terms of lateral resolution. In contrast, SIMS is limited in terms of detection of high molecular masses but offers orders of magnitude higher lateral resolution.

One of the big challenges in the next years will then be the integration of results that originate from different technological platforms. Van de Plas and coworkers have developed a multimodal approach in order to merge results coming for SEM and results coming from the MALDI imaging on mouse brain tissues. ${ }^{144}$ MSI (Mass Spectrometry Imaging) and SEM images have been combined through patch-based super resolution (PBSR) to generate images with enhanced information content. The final results combined the advantages of both technologies: sharpening of imaging mass spectrometry images and ion localization. One example of such merging is presented in Fig. 5, where a rat brain ion localization image has been obtained with a higher optical resolution using this approach. The same approach has already been developed for TOF-SIMS and SEM integration on algae cells. ${ }^{145}$ Images coming from different imaging modalities can also be merged in order to obtain high resolution images. ${ }^{\mathbf{1 4 6}}$

To conclude, TOF-SIMS can be helpful in many cases for cellular and molecular imaging. The biggest drawbacks of the technique (limited mass range and limited sensitivity) can be compensated using extra sample preparation steps or by combining TOF-SIMS with other established imaging techniques.

\section{Conflicts of interest}

There are no conflicts to declare.

\section{Acknowledgements}

This research was conducted as part of the M4I research program which is financially supported by the LINK program of the Dutch Province of Limburg. The authors also acknowledge the NWO-TTW UPON A3 project and the NWO-GWI NEMI (Netherlands Electron Microscopy Infrastructure) for the financial support.

\section{References}

1 R. Trouillon, M. K. Passarelli, J. Wang, M. E. Kurczy and A. G. Ewing, Anal. Chem., 2013, 85, 522-542.

2 A. Amantonico, P. L. Urban, S. R. Fagerer, R. M. Balabin and R. Zenobi, Anal. Chem., 2010, 82, 7394-7400.

3 K. Klepárník and F. Foret, Anal. Chim. Acta, 2013, 800, 1221.

4 R. Castaing and G. Slodzian, J. Microsc., 1962, 1, I960.

5 J. S. Fletcher, Analyst, 2009, 134, 2204.

6 E. J. Lanni, S. S. Rubakhin and J. V. Sweedler, J. Proteomics, 2012, 75, 5036-5051.

7 E. R. Amstalden van Hove, D. F. Smith and R. M. A. Heeren, J. Chromatogr. A, 2010, 1217, 3946-3954.

8 J. C. Vickerman, ToF-SIMS, 2001, 1-40.

9 L. A. McDonnell and R. M. A. Heeren, Mass Spectrom. Rev., 2007, 26, 606-643.

10 A. Benninghoven, Surf. Sci., 1994, 299-300, 246-260.

11 G. Slodzian, B. Daigne, F. Girard, F. Boust and F. Hillion, Biol. Cell., 1992, 74, 43-50.

12 H. W. Werner, Surf. Sci., 1975, 47, 301-323.

13 D. Touboul and A. Brunelle, Bioanalysis, 2016, 8, 367-369.

14 M. K. Passarelli and A. G. Ewing, Curr. Opin. Chem. Biol., 2013, 17, 854-859.

15 E. J. Lanni, S. J. B. Dunham, P. Nemes, S. S. Rubakhin and J. V. Sweedler, J. Am. Soc. Mass Spectrom., 2014, 25, 18971907.

16 D. Weibel, S. Wong, N. Lockyer, P. Blenkinsopp, R. Hill and J. C. Vickerman, Anal. Chem., 2003, 75, 1754-1764.

17 D. E. Weibel, N. Lockyer and J. C. Vickerman, Appl. Surf. Sci., 2004, 231-232, 146-152.

18 N. Davies, D. E. Weibel, P. Blenkinsopp, N. Lockyer, R. Hill and J. C. Vickerman, Appl. Surf. Sci., 2003, 203-204, 223227.

19 J. Cheng, J. Kozole, R. Hengstebeck and N. Winograd, J. Am. Soc. Mass Spectrom., 2007, 18, 406-412.

20 F. A. Fernandez-Lima, J. Post, J. D. DeBord, M. J. Eller, S. V. Verkhoturov, S. Della-Negra, A. S. Woods and E. A. Schweikert, Anal. Chem., 2011, 83, 8448-8453.

21 J. A. Townes, A. K. White, A. E. N. Wiggins, K. D. Krantzman, B. J. Garrison and N. Winograd, J. Phys. Chem. A, 1999, 103, 4587-4589.

22 F. Kollmer, W. Paul, M. Krehl and E. Niehuis, Surf. Interface Anal., 2013, 45, 312-314.

23 S. Sheraz née Rabbani, I. Berrueta Razo, T. Kohn, N. P. Lockyer and J. C. Vickerman, Anal. Chem., 2015, 87, 2367-2374.

24 S. Sheraz née Rabbani, A. Barber, I. Berrueta Razo, J. S. Fletcher, N. P. Lockyer and J. C. Vickerman, Surf. Interface Anal., 2014, 46, 51-53.

25 S. Rabbani, A. M. Barber, J. S. Fletcher, N. P. Lockyer and J. C. Vickerman, Anal. Chem., 2011, 83, 3793-3800.

26 N. Winograd, Anal. Chem., 2005, 77, 143-149.

27 Z. Ma, S. R. Coon, W. F. Calaway, M. J. Pellin, D. M. Gruen and E. I. von Nagy-Felsobuki, J. Vac. Sci. Technol., A, 1994, 12, 2425-2430. 
28 A. D. Appelhans and J. E. Delmore, Anal. Chem., 1989, 61, 1087-1093.

29 M. G. Blain, S. Della-Negra, H. Joret, Y. Le Beyec and E. A. Schweikert, Phys. Rev. Lett., 1989, 63, 1625-1628.

30 N. Winograd, Z. Postawa, J. Cheng, C. Szakal, J. Kozole and B. J. Garrison, Appl. Surf. Sci., 2006, 252, 6836-6843.

31 Z. Postawa, B. Czerwinski, M. Szewczyk, E. J. Smiley, N. Winograd and B. J. Garrison, J. Phys. Chem. B, 2004, 108, 7831-7838.

32 J. Xu, S. Ostrowski, C. Szakal, A. G. Ewing and N. Winograd, Appl. Surf. Sci., 2004, 231-232, 159-163.

33 A. M. Alnajeebi, J. C. Vickerman and N. P. Lockyer, Biointerphases, 2016, 11, $02 \mathrm{~A} 317$.

34 A. Tempez, J. A. Schultz, S. Della-Negra, J. Depauw, D. Jacquet, A. Novikov, Y. Lebeyec, M. Pautrat, M. Caroff, M. Ugarov, H. Bensaoula, M. Gonin, K. Fuhrer and A. Woods, Rapid Commun. Mass Spectrom., 2004, 18, 371376.

35 A. Novikov, M. Caroff, S. Della-Negra, J. Depauw, M. Fallavier, Y. Le Beyec, M. Pautrat, J. A. Schultz, A. Tempez and A. S. Woods, Rapid Commun. Mass Spectrom., 2005, 19, 1851-1857.

36 J. F. Mahoney, J. Perel, T. D. Lee, P. A. Martino and P. Williams, J. Am. Soc. Mass Spectrom., 1992, 3, 311-317.

37 T.-C. L. Wang, L. J. Cornio and S. P. Markey, J. Am. Soc. Mass Spectrom., 1996, 7, 293-297.

38 A. Heile, D. Lipinsky, N. Wehbe, A. Delcorte, P. Bertrand, A. Felten, L. Houssiau, J.-J. Pireaux, R. De Mondt, L. Van Vaeck and H. F. Arlinghaus, Appl. Surf. Sci., 2008, 255, 941-943.

39 M. E. Kurczy, P. D. Piehowski, S. A. Parry, M. Jiang, G. Chen, A. G. Ewing and N. Winograd, Appl. Surf. Sci., 2008, 255, 1298-1304.

40 O. Restrepo, A. Prabhakaran, K. Hamraoui, N. Wehbe, S. Yunus, P. Bertrand and A. Delcorte, Surf. Interface Anal., 2010, 42, 1030-1034.

41 M. Inoue, A. Murase, M. Yamamoto and S. Kubo, Appl. Surf. Sci., 2006, 252, 7014-7017.

42 K. J. Wu and R. W. Odom, Anal. Chem., 1996, 68, 873-882.

43 A. F. M. Altelaar, I. Klinkert, K. Jalink, R. P. J. de Lange, R. A. H. Adan, R. M. A. Heeren and S. R. Piersma, Anal. Chem., 2005, 78, 734-742.

44 A. Delcorte and P. Bertrand, Appl. Surf. Sci., 2004, 231-232, 250-255.

$45 \mathrm{H}$. Nygren, P. Malmberg, C. Kriegeskotte and H. F. Arlinghaus, FEBS Lett., 2004, 566, 291-293.

46 A. Delcorte, N. Médard and P. Bertrand, Anal. Chem., 2002, 74, 4955-4968.

47 A. Delcorte, J. Bour, F. Aubriet, J.-F. Muller and P. Bertrand, Anal. Chem., 2003, 75, 6875-6885.

48 M. Inoue and A. Murase, Surf. Interface Anal., 2005, 37, 1111-1114.

49 S. J. B. Dunham, T. J. Comi, K. Ko, B. Li, N. F. Baig, N. Morales-Soto, J. D. Shrout, P. W. Bohn and J. V. Sweedler, Biointerphases, 2016, 11, $02 \mathrm{~A} 325$.

50 M. J. Eller, A. Vinjamuri, B. E. Tomlin and E. A. Schweikert, Anal. Chem., 2018, 90, 12692-12697.
51 A. Delcorte, S. Yunus, N. Wehbe, N. Nieuwjaer, C. Poleunis, A. Felten, L. Houssiau, J.-J. Pireaux and P. Bertrand, Anal. Chem., 2007, 79, 3673-3689.

52 L. Adriaensen, F. Vangaever, R. Gijbels, L. Adriaensen, F. Vangaever and R. Gijbels, Anal. Chem., 2004, 76, 67776785.

53 A. S. Mohammadi, J. S. Fletcher, P. Malmberg and A. G. Ewing, Surf. Interface Anal., 2014, 46, 379-382.

54 B. Flinders, E. Cuypers, H. Zeijlemaker, J. Tytgat and R. M. A. Heeren, Drug Test. Anal., 2015, 7, 859-865.

55 E. Cuypers, B. Flinders, C. M. Boone, I. J. Bosman, K. J. Lusthof, A. C. Van Asten, J. Tytgat and R. M. A. Heeren, Anal. Chem., 2016, 88, 3091-3097.

56 F. N. Svara, A. Kiss, T. W. Jaskolla, M. Karas and R. M. A. Heeren, Anal. Chem., 2011, 83, 8308-8313.

57 J. E. Locklear, C. Guillermier, S. V. Verkhoturov and E. A. Schweikert, Appl. Surf. Sci., 2006, 252, 6624-6627.

58 S. L. McArthur, M. C. Vendettuoli, A. B. D. Ratner and D. G. Castner, Langmuir, 2004, 20, 3704-3709.

59 S. L. Luxembourg, L. A. McDonnell, M. C. Duursma, A. Xinghua Guo and R. M. A. Heeren, Anal. Chem., 2003, 75, 2333-2341.

60 L. A. McDonnell, S. R. Piersma, A. F. M. Altelaar, T. H. Mize, S. L. Luxembourg, P. D. E. M. Verhaert, J. van Minnen and R. M. A. Heeren, J. Mass Spectrom., 2005, 40, 160-168.

61 A. F. M. Altelaar, J. van Minnen, C. R. Jiménez, R. M. A. Heeren and S. R. Piersma, Anal. Chem., 2005, 77, 735-741.

62 T. D. Do, T. J. Comi, S. J. B. Dunham, S. S. Rubakhin and J. V. Sweedler, Anal. Chem., 2017, 89, 3078-3086.

63 R. D. Macfarlane, Acc. Chem. Res., 1982, 15, 268-275.

64 P. Håkansson, I. Kamensky, B. Sundqvist, J. Fohlman, P. Peterson, C. J. McNeal and R. D. Macfarlane, J. Am. Chem. Soc., 1982, 104, 2948-2949.

65 O. D. Sanni, M. S. Wagner, D. Briggs, D. G. Castner and J. C. Vickerman, Surf. Interface Anal., 2002, 33, 715-728.

66 M. S. Wagner and D. G. Castner, Appl. Surf. Sci., 2004, 231232, 366-376.

67 S. Muramoto, D. J. Graham, M. S. Wagner, T. G. Lee, D. W. Moon and D. G. Castner, J. Phys. Chem. C, 2011, 115, 24247-24255.

68 D. S. Mantus, B. D. Ratner, B. A. Carlson and J. F. Moulder, Anal. Chem., 1993, 65, 1431-1438.

69 M. S. Wagner and D. G. Castner, Langmuir, 2001, 17, 46494660.

70 M. Henry, C. Dupont-Gillain and P. Bertrand, Langmuir, 2003, 19, 6271-6276.

71 C. Brüning, S. Hellweg, S. Dambach, D. Lipinsky and H. F. Arlinghaus, Surf. Interface Anal., 2006, 38, 191-193.

72 N. Xia and D. G. Castner, J. Biomed. Mater. Res., Part A, 2003, 67, 179-190.

73 Y.-P. Kim, M.-Y. Hong, J. Kim, E. Oh, H. K. Shon, D. W. Moon, H.-S. Kim and T. G. Lee, Anal. Chem., 2007, 79, 1377-1385.

74 N. Ogrinc Potočnik, G. L. Fisher, A. Prop and R. M. A. Heeren, Anal. Chem., 2017, 89, 8223-8227. 
75 C. Enjalbal, D. Maux, G. Subra, J. Martinez, R. Combarieu and J.-L. Aubagnac, Tetrahedron Lett., 1999, 40, 6217-6220.

76 H. Nygren and P. Malmberg, Proteomics, 2010, 10, 16941698.

77 H. F. Arlinghaus, M. Ostrop, O. Friedrichs, J. Feldner, U. Gunst and D. Lipinsky, Surf. Interface Anal., 2002, 34, 35-39.

78 A. Benninghoven, J. Vac. Sci. Technol., A, 1985, 3, 451-460.

79 C.-Y. Lee, G. M. Harbers, D. W. Grainger, L. J. Gamble and D. G. Castner, J. Am. Chem. Soc., 2007, 129, 9429-9438.

80 A. N. Rao, N. Vandencasteele, L. J. Gamble and D. W. Grainger, Anal. Chem., 2012, 84, 10628-10636.

81 G. P. Moss, P. A. S. Smith and D. Tavernier, Pure Appl. Chem., 1995, 67, 1307-1375.

82 E. Muro, G. E. Atilla-Gokcumen and U. S. Eggert, Mol. Biol. Cell, 2014, 25, 1819-1823.

83 M. K. Passarelli and N. Winograd, Biochim. Biophys. Acta, Mol. Cell Biol. Lipids, 2011, 1811, 976-990.

84 M. L. Kraft and H. A. Klitzing, Biochim. Biophys. Acta, Mol. Cell Biol. Lipids, 2014, 1841, 1108-1119.

85 N. Tahallah, A. Brunelle, S. De La Porte and O. Laprévote, J. Lipid Res., 2008, 49, 438-454.

86 P. Sjövall, J. Lausmaa and B. Johansson, Anal. Chem., 2004, 76, 4271-4278.

87 N. T. N. Phan, J. S. Fletcher, P. Sjövall and A. G. Ewing, Surf. Interface Anal., 2014, 46, 123-126.

88 K. Škrášková, A. Khmelinskii, W. M. Abdelmoula, S. De Munter, M. Baes, L. McDonnell, J. Dijkstra and R. M. A. Heeren, J. Am. Soc. Mass Spectrom., 2015, 26, 948957.

89 F. Benabdellah, A. Seyer, L. Quinton, D. Touboul, A. Brunelle and O. Laprévote, Anal. Bioanal. Chem., 2010, 396, 151-162.

90 Q. P. Vanbellingen, N. Elie, M. J. Eller, S. Della-Negra, D. Touboul and A. Brunelle, Rapid Commun. Mass Spectrom., 2015, 29, 1187-1195.

91 B. Johansson, Surf. Interface Anal., 2006, 38, 1401-1412.

92 V. Thiel, C. Heim, G. Arp, U. Hahmann, P. Sjövall and J. Lausmaa, Geobiology, 2007, 5, 413-421.

93 D. Debois, M.-P. Bralet, F. Le Naour, A. Brunelle and O. Laprévote, Anal. Chem., 2009, 81, 2823-2831.

94 Y. Magnusson, P. Friberg, P. Sjövall, F. Dangardt, P. Malmberg and Y. Chen, Clin. Physiol. Funct. Imaging, 2008, 28, 202-209.

95 A. N. Lazar, C. Bich, M. Panchal, N. Desbenoit, V. W. Petit, D. Touboul, L. Dauphinot, C. Marquer, O. Laprévote, A. Brunelle and C. Duyckaerts, Acta Neuropathol., 2013, 125, 133-144.

96 P. Sjövall, J. Lausmaa, H. Nygren, L. Carlsson and P. Malmberg, Anal. Chem., 2003, 75, 3429-3434.

97 P. Malmberg, H. Nygren, K. Richter, Y. Chen, F. Dangardt, P. Friberg and Y. Magnusson, Microsc. Res. Tech., 2007, 70, 828-835.

98 E. B. Monroe, S. P. Annangudi, N. G. Hatcher, H. B. Gutstein, S. S. Rubakhin and J. V. Sweedler, Proteomics, 2008, 8, 3746-3754.
99 A. F. M. Altelaar, J. van Minnen, R. M. A. Heeren and S. R. Piersma, Appl. Surf. Sci., 2006, 252, 6702-6705.

100 E. B. Monroe, J. C. Jurchen, J. Lee, S. S. Rubakhin, J. V. Sweedler, E. B. Monroe, J. C. Jurchen, J. Lee, S. S. Rubakhin and J. V. Sweedler, J. Am. Chem. Soc., 2005, 127, 12152-12153.

101 H. L. Kotze, E. G. Armitage, J. S. Fletcher, A. Henderson, K. J. Williams, N. P. Lockyer and J. C. Vickerman, Surf. Interface Anal., 2013, 45, 277-281.

102 D. F. Smith, A. Kiss, F. E. Leach, E. W. Robinson, L. PašaTolić and R. M. A. Heeren, Anal. Bioanal. Chem., 2013, 405, 6069-6076.

103 S. Maharrey, R. Bastasz, R. Behrens, A. Highley, S. Hoffer, G. Kruppa and J. Whaley, Appl. Surf. Sci., 2004, 231-232, 972-975.

104 J. Alvarez, R. G. Cooks, S. E. Barlow, D. J. Gaspar, A. J. H. Futrell and J. Laskin, Anal. Chem., 2005, 77, 34523460.

105 M. E. Castro and D. H. Russell, Anal. Chem., 1984, 56, 578581.

106 M. E. Castro and D. H. Russell, Anal. Chem., 1985, 57, 22902293.

107 J. D. DeBord, D. F. Smith, C. R. Anderton, R. M. A. Heeren, L. Paša-Tolić, R. H. Gomer and F. A. Fernandez-Lima, PLoS One, 2014, 9, e99319.

108 G. L. Fisher, A. L. Bruinen, N. Ogrinc Potočnik, J. S. Hammond, S. R. Bryan, P. E. Larson and R. M. A. Heeren, Anal. Chem., 2016, 88, 6433-6440.

109 A. L. Bruinen, G. L. Fisher and R. M. A. Heeren, in Imaging Mass Spectrometry: Methods and Protocols, Methods in Molecular Biology, Humana Press, New York, NY, 2017, pp. 165-173.

110 G. L. Fisher, J. S. Hammond, P. E. Larson, S. R. Bryan and R. M. A. Heeren, J. Vac. Sci. Technol., B: Nanotechnol. Microelectron.: Mater., Process., Meas., Phenom., 2016, 34, $03 \mathrm{H} 126$.

111 P. D. Piehowski, A. J. Carado, M. E. Kurczy, S. G. Ostrowski, M. L. Heien, N. Winograd and A. G. Ewing, Anal. Chem., 2008, 80, 8662-8667.

112 Y. Yokoyama, S. Aoyagi, M. Fujii, J. Matsuo, J. S. Fletcher, N. P. Lockyer, J. C. Vickerman, M. K. Passarelli, R. Havelund and M. P. Seah, Anal. Chem., 2016, 88, 35923597.

113 A. D. Palmer and T. Alexandrov, Anal. Chem., 2015, 87, 4055-4062.

114 E. H. Seeley and R. M. Caprioli, Anal. Chem., 2012, 84, 21052110.

115 J. S. Fletcher, Biointerphases, 2015, 10, 018902.

116 R. Hill, P. Blenkinsopp, S. Thompson, J. Vickerman and J. S. Fletcher, Surf. Interface Anal., 2011, 43, 506-509.

117 L. Fornai, A. Angelini, I. Klinkert, F. Giskes, A. Kiss, G. Eijkel, E. A. A. Hove, L. A. Klerk, M. Fedrigo, G. Pieraccini, G. Moneti, M. Valente, G. Thiene and R. M. A. Heeren, Anal. Bioanal. Chem., 2012, 404, 29272938.

118 I. Klinkert, K. Chughtai, S. R. Ellis and R. M. A. Heeren, Int. J. Mass Spectrom., 2014, 362, 40-47. 
119 H. Hutter, K. Nowikow and K. Gammer, Appl. Surf. Sci., 2001, 179, 161-166.

120 S. Van Nuffel, C. Parmenter, D. J. Scurr, N. A. Russell and M. Zelzer, Analyst, 2016, 141, 90-95.

121 J. S. Fletcher, N. P. Lockyer, A. Seetharaman Vaidyanathan and J. C. Vickerman, Anal. Chem., 2007, 187, 89-100.

122 J. Brison, M. A. Robinson, D. S. W. Benoit, S. Muramoto, P. S. Stayton and D. G. Castner, Anal. Chem., 2013, 85, 10869-10877.

123 J. Brison, D. S. W. Benoit, S. Muramoto, M. Robinson, P. S. Stayton and D. G. Castner, Surf. Interface Anal., 2011, 43, 354-357.

124 T. Miyayama, N. Sanada, S. R. Bryan, J. S. Hammond and M. Suzuki, Surf. Interface Anal., 2010, 42, 1453-1457.

125 A. Castellanos, C. E. Ramirez, V. Michalkova, M. Nouzova, F. G. Noriega and F. Fernández-Lima, J. Anal. At. Spectrom., 2019, 34, 874-883.

126 M. Körsgen, A. Pelster, K. Dreisewerd and H. F. Arlinghaus, J. Am. Soc. Mass Spectrom., 2016, 27, 277-284.

127 Q. P. Vanbellingen, A. Castellanos, M. Rodriguez-Silva, I. Paudel, J. W. Chambers and F. A. Fernandez-Lima, J. Am. Soc. Mass Spectrom., 2016, 27, 2033-2040.

128 J. S. Fletcher, N. P. Lockyer and J. C. Vickerman, Mass Spectrom. Rev., 2011, 30, 142-174.

129 S. Vaidyanathan, J. S. Fletcher, R. Goodacre, N. P. Lockyer, J. Micklefield and J. C. Vickerman, Anal. Chem., 2008, 80, 1942-1951.

130 M. A. Robinson, D. J. Graham and D. G. Castner, Anal. Chem., 2012, 84, 4880-4885.

131 D. Mao, A. Wucher, D. A. Brenes, C. Lu and N. Winograd, Anal. Chem., 2012, 84, 3981-3989.

132 M. P. Seah, R. Havelund and I. S. Gilmore, J. Phys. Chem. C, 2016, 120, 26328-26335.
133 L. Breuer, N. J. Popczun, A. Wucher and N. Winograd, J. Phys. Chem. C, 2017, 121, 19705-19715.

134 T. Leefmann, C. Heim, A. Kryvenda, S. Siljeström, P. Sjövall and V. Thiel, Org. Geochem., 2013, 57, 23-33.

135 T. L. Colliver, C. L. Brummel, M. L. Pacholski, F. D. Swanek, A. G. Ewing and N. Winograd, Anal. Chem., 1997, 69, 22252231.

136 P. D. Piehowski, M. E. Kurczy, D. Willingham, S. Parry, M. L. Heien, N. Winograd and A. G. Ewing, Langmuir, 2008, 24, 7906-7911.

137 B. K. Kaletaş, I. M. van der Wiel, J. Stauber, L. J. Lennard, J. Dekker, C. Güzel, J. M. Kros, T. M. Luider and R. M. A. Heeren, Proteomics, 2009, 9, 2622-2633.

138 L. Wu, X. Lu, K. S. Kulp, M. G. Knize, E. S. F. Berman, E. J. Nelson, J. S. Felton and K. J. J. Wu, Int. J. Mass Spectrom., 2007, 260, 137-145.

139 A. R. Buchberger, K. DeLaney, J. Johnson and L. Li, Anal. Chem., 2018, 90, 240-265.

140 K. Konig, J. Microsc., 2000, 200, 83-104.

141 A. J. Walsh and M. C. Skala, Biomed. Opt. Express, 2015, 6, 559.

142 E. R. Amstalden Van Hove, T. R. Blackwell, I. Klinkert, G. B. Eijkel, R. M. A. Heeren and K. Glunde, Cancer Res., 2010, 70, 9012-9021.

143 E. J. Lanni, R. N. Masyuko, C. M. Driscoll, J. T. Aerts, J. D. Shrout, P. W. Bohn and J. V. Sweedler, Anal. Chem., 2014, 86, 9139-9145.

144 R. Van de Plas, J. Yang, J. Spraggins and R. M. Caprioli, Nat. Methods, 2015, 12, 366-372.

145 J. G. Tarolli, L. M. Jackson and N. Winograd, J. Am. Soc. Mass Spectrom., 2014, 25, 2154-2162.

146 K. Ščupáková, V. Terzopoulos, S. Jain, D. Smeets and R. M. A. Heeren, Sci. Rep., 2019, 9, 2915. 